NBER WORKING PAPER SERIES

\title{
TRADING AND THE TAX SHELTER VALUE \\ OF DEPRECIABLE REAL ESTATE
}

Patric H. Hendershott

David C. Ling

Working Paper No. 1267

NATIONAL BUREAU OF ECONOMIC RESEARCH

1050 Massachusetts Avenue

Cambridge, MA 02138

January 1984

The research reported here is part of the NBER's research program in Taxation. Any opinions expressed are those of the authors and not those of the National Bureau of Economic Research. 
NBER Working Paper $\$ 1267$ January 1984

Trading and the Tax Shelter Value of Depreciable Real Estate

\section{$\underline{\text { ABSTRACT }}$}

For well-diversified investors in depreciable real estate, the trading decision may be made with the sole objective of maximizing the property's depreciation tax shelter net of all capital gain taxes and transaction costs. This paper develops a dynamic programming model in which the optimal trading strategies and depreciation methods of all investors in a property are simultaneously determined. The effects of inflation, depreciation, recapture and choice of depreciation method are analyzed, and the costs of suboptimal trading are measured. The model is applied to both conventional residential and commercial income properties under post-ERTA tax rules. At single digit inflation rates, properties are traded multiple times, and the costs of suboptimal trading are significant.

Patric H. Hendershott Hagerty Hall Ohio State University 1775 College Road Columbus, $\mathrm{OH} \quad 43210$ (614) 422-0552
David C. Ling Faculty of Finance University of Florida Gainesville, Florida 32611 (904) 392-1330 
Trading and the Tax Shelter Value of Income Properties

Patric H. Hendershott and David C. Ling

In a taxless, riskless world with no transactions costs, all investments would earn the same before-tax equilibrium real rate of return. Furthermore, this competitive return would be earned regardless of how long the asset was held. In a world characterized by the current federal income tax system, scarce capital resources in the economy are allocated between sectors on the basis of expected posttax rates of return. Capital will move between sectors of the economy, and relative prices will adjust, until real, risk-adjusted posttax yields are the same, at the margin, for all capital goods. Taxing the income from one type of capital, say income-producing real estate, less heavily than other types of capital will simply result in more of the tax preferred income being supplied. Market prices, and hence supply, will reflect the extent to which income-producing real estate is a tax preferred asset. Additionally, the investment value of real estate income property will no longer be independent of how long the asset was held. Any differential benefits that are expected from trading the asset at the optimal time are capitalized into the initial value. Because competitive market prices reflect the optimal holding period of the marginal investor, any theory of real estate asset prices in the presence of federal income taxes must contain a theory of optimal holding periods.

Another issue of importance is the relationship between tax law and capital gain realizations. Because capital gain taxes are only paid in the year the asset is sold, investors may be "locked-in" to assets that do not offer the best available return. surely Congressmen had this phenomenon in mind when they claimed that tax revenues will not decline as a result of a cut 
in the capital gain tax rate. The additional transactions induced by the tax cut would, it has been argued, offset the impact of a decline in the rate at which such realizations are taxed. Any analysis that addresses the question of how changes in tax law affect realizations must be built upon a theory of optimal holding periods.

Recent research dealing with the selection of depreciation methods and optimal holding periods has emphasized the importance of tax considerations. Depreciation deductions allowed the current owner are based on his original acquisition cost of the property, while those of a potential new owner are based on the current market value. For this reason, the new owner will, in an inflationary environment, place a higher value on the remaining stream of depreciation deductions available from the property than will the existing owner. However, for the new owner to establish the current market price of the property as his initial depreciation base, the current owner must sell the property and thereby realize, in most cases, a taxable capital gain. If accelerated depreciation had been employed, then a portion of the gain will be recaptured at ordinary income tax rates. This recapture of excess depreciation reduces dollar for dollar the amount of the gain that is converted from ordinary income to capital gain income. Aside from these tax considerations, brokerage transaction costs are also incurred when the property is sold. All of these costs of achieving the higher depreciation base, which we label "selling" costs, discourage the realization of capital gains.

The holding period model developed by Brueggeman, Fisher and stern (1981) (1982) explicitly considers the impact of these selling costs on optimal trading strategies, but the model assumes that the second owner never sells the property. ${ }^{l}$ This paper extends their analysis by developing a 
holding period model in which both the optimal trading strategies and depreciation methods of all investors in a property are simultaneously determined. Application of our model suggests that one-time trading is generally suboptimal under ERTA tax law and a wide range of assumed expected inflation and discount rates and leads to a significant under valuation of the net tax shelter component of the return to income properties.

The paper is organized as follows. Section I reviews the earlier literature for determining the optimal trading strategy of the initial investor under the assumption that the real estate will only be sold once during its economic life. In section II a dynamic programming model is developed to account for the multistage nature of the "sell or hold" decision making process. Section III applies the model to properties purchased after the passage of the Economic Recovery Tax Act (ERTA) of 1981. The effects of inflation, recapture and choice of depreciation method are analyzed and the costs of suboptimal trading are measured. Both residential and commercial properties are considered. The paper concludes with a brief summary.

\section{THE SINGLE TRADE HOLDING PERIOD MODEL ${ }^{2}$}

When evaluating an income producing property, the investor must determine, ex ante, the optimal investment holding period. One possible strategy is to hold the property to the end of its economic life. The value of the depreciable portion of the property (the "improvements") to the first owner, assuming al1-equity finance, is

$$
v_{0}=\sum_{i=1}^{n} \frac{\left(1-t_{0}\right) I_{i}+t_{0} D_{i}^{1}}{(1+K)^{i}},
$$


where $V_{0}$ - the initial value of property

$I_{i}$ - net income from operations in year $i$

$t_{0}$ - marginal tax rate on ordinary income

$D_{i}^{1}$ - tax depreciation allowed the investor in year $i$

$\mathrm{K}$ - required after-tax rate of return

$\mathrm{n}$ - number of years of economic life.

During periods of rising property values, the depreciation tax shelter benefits associated with the property can be increased by trading the property. However, in order to achieve this increase in tax shelter value, the seller must realize a taxable capital gain, pay any recapture penalties, and incur transaction costs. The initial value of the property assuming sale in the year $\mathrm{s}$ is

$$
V_{0}=\sum_{i=1}^{n} \frac{\left(1-t_{0}\right) I_{i}+t_{0} D_{i}}{(1+K)^{i}}+\frac{P_{s}-\left(t_{g} G_{g}+t_{0} R_{s}+\beta P_{s}\right)}{(1+K) s}
$$

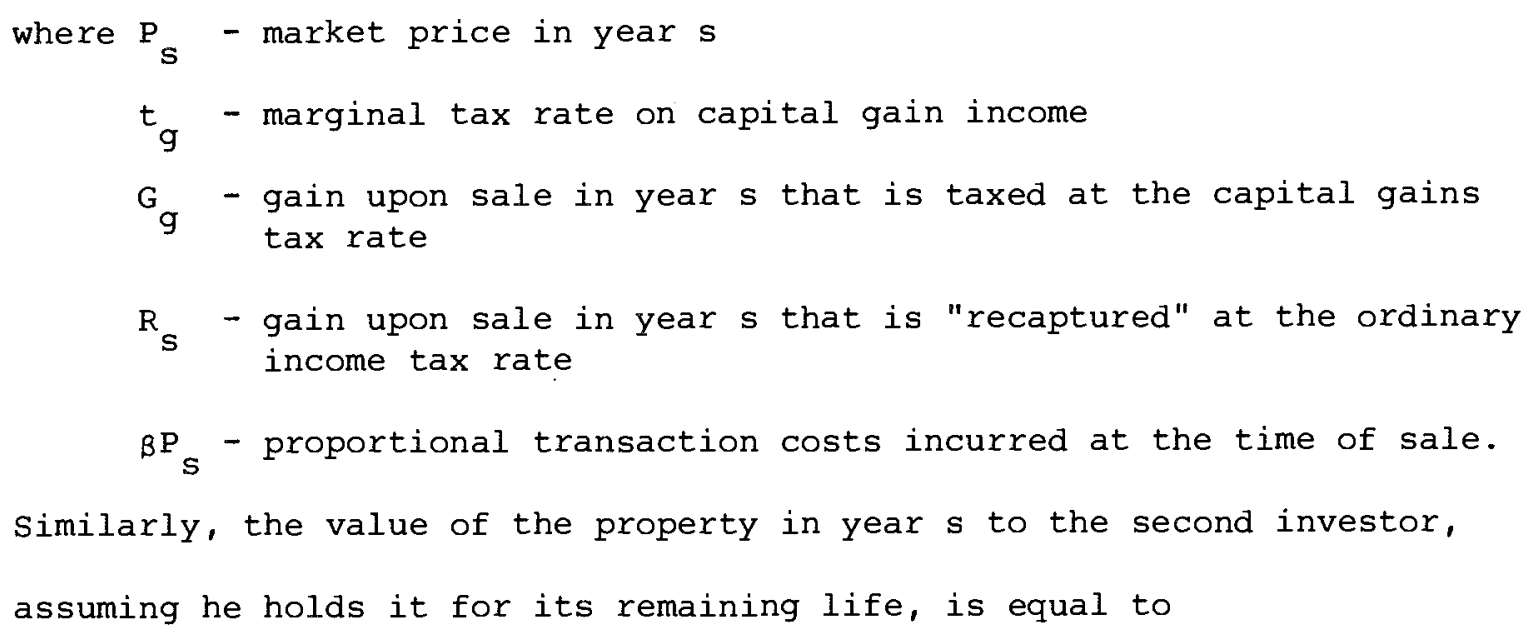




$$
P_{S}=\sum_{i=s+1}^{n} \frac{\left(1-t_{0}\right) I_{i}+t_{0} D_{i}^{2}}{(1+K)}
$$

where $D_{i}^{2}$ is the tax depreciation allowed the second investor in year $i$.

If it is assumed that the property will be traded only once during its economic life, the initial investor will plan to sell in the year that maximizes the net marginal tax benefits from selling the property relative to the tax benefits that accrue to the owner if the property is never sold. That is, investors will choose, ex ante, the holding period s that maximizes

$$
\Delta V_{0}=\frac{1}{(1+K)}\left[\sum_{i=s+1}^{n} \frac{t_{0}\left(D_{i}^{2}-D_{i}^{l}\right)}{(1+K)^{i-s}}-\left(t_{g} G_{s}+t_{0} R_{s}+\beta P_{s}\right)\right]
$$

where $\Delta \mathrm{V}_{\mathrm{O}}$ is the increase in the present value of the property that results from a sale in year $s$, instead of holding the property for the remainder of its economic life. Equation (4) is derived by subtracting (1) from (2) after substitution of (3). The summation within the brackets is the present value, in year s, of the incremental depreciation deductions that will result from the trade, assuming the second investor never sells the property. The remaining terms within the brackets represent the total selling costs that would be incurred as a result of a sale in year $s$.

Expression (4) computes the amount that investors gain from or lose to the Treasury as a result of a sale in year s. ${ }^{3}$ Note that net operating income does not appear in the expression; maximization of the property's net tax shelter benefits is a sufficient condition for maximization of total investment value. The gain from the Treasury varies with the 
year of sale in two ways. First, capital gains are taxed only upon realization, not as they accrue. The government effectively lends investors the amount of their accrued tax liability (assuming positive gains) at a zero rate of interest. Second, the nominal, rather than the real, gain is taxed at the time of sale. With positive inflation, the former benefits investors and the latter penalizes them.

While the "one-time trade" model explicitly considers the costs incurred in establishing a new depreciation base, the model rests upon the assumption that the second owner never seils the property. Define the variable

$$
B=\sum_{i=s+1}^{n} \frac{t_{0}\left(D_{i}^{2}-D_{i}^{1}\right)}{(1+K)^{i-s}}-\left(t_{g} G_{s}+t_{0} R_{s}+\beta P_{s}\right)
$$

and note that $\mathrm{B}>0$ is a necessary condition for trading in any year $s$. That is, the present value of the incremental tax depreciation that would result from a trade must at least exceed the selling costs that would be incurred. However, $B>0$ is not a sufficient condition for a trade to occur. In fact, the one-time trade model assumes, ex ante, that the trade will not be made until the discounted value of $B$ reaches its maximum. In this formulation, then, the trade decision depends upon both the sign and the magnitude of B. By assuming that the property is only traded once, the model places a minimum value on the incremental tax depreciation (and hence B) that would result from a sale. Consequently, the initial holding period will tend to be overstated, and the tax shelter value will definitely be understated (unless only one trade is optimal). 
THE DYNAMIC PROGRAMMING MODEL 4

An economic life of 70 years is assumed for the improvements

(depreciable portion of the property), based on earlier work by Taubman and Rasche (1969) and Hulten and Wykoff (1978). This means that the decision making process contains 70 "stages" with a sell or hold decision required at each stage. Specifically, the owner in each stage must determine, given the tax "age" of the asset, whether to sell the property in that year or hold it for an additional year. The tax age of the improvements, in any stage, equals the number of years since the property was last traded. The decisions are interrelated in that tax age depends upon whether or not a trade was made in the previous stage (year). Stages run in descending numerical order so that, for example, 10 years after the start of the process, there are 60 stages remaining .

In broad outline the method of solution is as follows. The value of the tax shelter is determined at stage 1 (the last stage of the process) for each possible tax age (69 in all) state assuming the property is sold to a developer at the end of this last stage for the prevailing market price of the land. The optimal decision and the resulting tax shelter value are then determined for each possible tax age at stages 1,2, etc., working backwards through time until all stages have been dealt with. The computer algorithm stores optimal decisions and tax shelter values for each possible stage and tax age. The value at stage 70 is the current present value of the tax shelter net of all selling costs. The optimal holding period for the first investor is determined by starting at this initial stage and following the optimal plan just determined until the stage is reached where the optimal decision is to sell.

The depreciation deduction on a property of tax age $s$ taken in stage $t$ $[d(t, s)]$ is 


$$
d(t, s)=f(s) b_{0}(t+s-1) \text {, }
$$

where $s$ is the current tax age of the improvements, $f(s)$ is the applicable depreciation factor ${ }^{5}$, and $b_{0}(t+s-1)$ is the original depreciation base of the property. It is assumed that the depreciation deduction is taken at the end of the stage. If the property is sold in stage $t$ and straight-line depreciation had been employed, the seller incurs a cash outflow $[c(t, s)]$ of

$$
c(t, s)=\beta P_{s}+t_{g}\left[(1-\beta) P_{s}-b_{a}(t, s)\right]
$$

where $t_{g}$ is the marginal capital gains tax rate and $b_{a}(t, s)$ is the adjusted depreciable basis. ${ }^{6}$ Sales are also assumed to occur at the end of the stage. The net cash inflow from the tax shelter equals the after-tax value of the depreciation deduction (minus selling costs if the decision is made to sell). 7 Thus this inflow in stage $t[r(t, s, a)]$ is

$$
r(t, s, a)= \begin{cases}t_{0} d(t, s) & \text { for } a=1 \\ t_{0} d(t, s)-c(t, s) & \text { for } a=2\end{cases}
$$

where $a$ is an element of the decision set $A(1=$ hold, $2=\operatorname{sell})$. An investor holding a property of tax age $s$ in stage $t$ will make the decision (sell or hold) that maximizes

$$
V(t, s)=\operatorname{MAX}_{a \in A}\left[\frac{r(t, s, a)}{1+K}+\frac{V(t-1, j)}{1+K}\right],
$$


where $V(t, s)$ is the present value of the tax shelter at the beginning of stage $t$ and $K$ is the after-tax discount rate. $V(t-1, j)$ is the value of the tax shelter at the beginning of the next stage. This value depends upon the tax age of the asset which, in turn, depends upon the action that is taken at the end of the current stage. If the property is not sold, $j=s+1$. If a sale occurs, $j=1.8$

A sufficient condition for a trade to occur in stage $t$ is

$$
V(t-1,1)-V(t-1, s+1)>c(t, s)
$$

That is, both the current owner and a potential buyer will gain relative to the Treasury if the incremental value of the tax shelter resulting from a sale exceeds the total selling costs incurred by the current owner. In a competitive market, such opportunities will be exploited at the expense of the Treasury.

\section{THE RESULTS}

The simulations are based upon the ERTA tax law which offers identical tax depreciation options to investors in conventional residential and commercial income properties -- 175 percent declining balance or straight-line with a 15 year cost recovery period. Two patterns of economic depreciation for the improvements are employed in the simulations -- reverse sum of years (RSY) and straight-line (SL), both over the 70 year economic life. The former assumption is implied by the work of Taubman and Rasche (1969), while the latter is consistent with the more recent findings of Hulten and Wykoff (1978). The land portion of the property constitutes 20 percent of the 
initial purchase price and is assumed to grow in nominal value at the rate of inflation. This implies that the percentage of the nominal property price that represents depreciable improvements decreases through time.

Expected inflation rates ( $\left.\pi^{\prime} s\right)$ of $3,6,9$, and 12 percent are' considered. To arrive at the nominal price pattern under each inflation rate scenario, the estimated real value of the land plus improvements in each year is compounded by the appropriate inflation rate factor.

For investors in low to medium tax brackets a reasonable required rate of return is the after-tax mortgage interest rate because fully taxable bonds and mortgages are reasonable investment alternatives for such investors. For higher tax bracket individuals, however, tax exempt securities provide a better after-tax rate of return. Because the long-term municipal bond rate has generally been 70 percent of the fully taxable rate, the after-tax discount rate $(K)$ is assumed to be 70 percent of the nominal mortgage interest rate. This assumption implies that the depreciation tax shelter is in the same risk class as long-term municipal debt. The justification for this assumption is that the tax shelter portion of the investor's return is fairly certain. It is the cash flows from operations that are quite risky. The nominal mortgage rate $(R)$ is assumed to be equal to the product of the assumed constant real rate of return (.03) and the expected inflation rate ( $\pi$ ) or $R=(1.03)(1+\pi)-1$. Because $K=0.7 R$, it declines with increases in anticipated inflation. Consequently, this is labeled the low discount rate case. To test the sensitivity of the results to the specification of $k$, the nominal mortgage interest rate will also be assumed to rise by a multiple of $\pi$. More specifically, $0.7 R=(1.03)(1+\pi)-1$. Given that $k=0.7 R$, this assumption 
is equivalent to assuming that the after-tax discount rate rises "one-for-one" with expected inflation, rather than declining. This specification of $\mathrm{R}$ and $\mathrm{K}$ is labeled the high discount rate case. ${ }^{9}$

We assume that investors are able to costlessly maintain optimal loanto-value ratios so that, at the margin, they are indifferent to the method of financing. ${ }^{10}$ Finally, transactions costs are assumed to be equal to 5 percent of the nominal sales price. ${ }^{11}$

\section{Residential Property}

Results for residential property are displayed in Table 1. Two statistics are reported: (1) the present value of the depreciation tax shelter, net of all selling costs, per dollar of the original purchase price, and (2) the holding period of each investor assuming the exclusive use of accelerated depreciation throughout the life of the property. The latter is assumed because under any set of parameter values the use of accelerated depreciation maximizes the value of the tax shelter and therefore dominates the straight-line alternative (compare the SL and ACC columns in Table 1 ). ${ }^{12}$

The frequency of trading declines with increases in the expected rate of inflation. With RSY economic depreciation, a relatively low discount rate $(\partial R / \partial \pi=1.03)$, and 3 percent inflation, the property is held by 5 different investors. This number decreases as the expected inflation rate increases; at 12 percent inflation, the original purchaser never sells. Under these circumstances, the increase in tax shelter value that would result from a sale in any year is never sufficient to offset the selling (tax and realtors fees) costs that would be incurred because inflated nominal gains, rather than real gains, are taxed at the time of sale. clearly, inflation-induced taxes can cause investors to be locked-in to properties. 
TABLE 1

RESIDENTIAL PROPERTY

OPTIMAL HOLDING PERIODS AND THE INITIAL VALUE OF THE TAX SHELTER PER DOLLAR OF ORIGINAL PURCHASE PRICE $[\mathrm{V}(70,1) / \mathrm{P}]$

\begin{tabular}{|c|c|c|c|c|c|c|c|c|c|}
\hline & \multirow{2}{*}{$\frac{\partial R}{\partial \pi}$} & ECONOMIC & \multicolumn{2}{|c|}{$V(70,1) / P$} & \multicolumn{2}{|c|}{ HOLDING } & PERIOD BY & \multicolumn{2}{|c|}{ INVESTOR * } \\
\hline & & ECIATION & SL & $A C C$ & 1 & 2 & 3 & 4 & 5 \\
\hline \multirow{3}{*}{$\pi=38$} & 1.03 & SL & .36 & .39 & 15 & 15 & 15 & 25 & \multirow{3}{*}{10} \\
\hline & 1.03 & RSY & .40 & .44 & 15 & 15 & 15 & 15 & \\
\hline & $1.03 / 0.7$ & RSY & .30 & .34 & 15 & 15 & 15 & 25 & \\
\hline \multirow{3}{*}{$\pi=68$} & 1.03 & SL & .23 & .28 & 15 & 15 & 15 & 25 & \\
\hline & 1.03 & RSY & .27 & .33 & 15 & 15 & 15 & 25 & \\
\hline & $1.03 / 0.7$ & RSY & .21 & .24 & 15 & 15 & 40 & & \\
\hline \multirow{3}{*}{$\pi=98$} & 1.03 & SL & .16 & .18 & 15 & 55 & \multirow{3}{*}{40} & & \\
\hline & 1.03 & RSY & .16 & .20 & 15 & 15 & & & \\
\hline & $1.03 / 0.7$ & RSY & .17 & .20 & 70 & & & & \\
\hline \multirow{3}{*}{$\pi=12 \%$} & 1.03 & SL & .09 & . & 70 & & & & \\
\hline & 1.03 & RSY & .09 & .11 & 70 & & & & \\
\hline & $1.03 / 0.7$ & RSY & .15 & .17 & 70 & & & & \\
\hline
\end{tabular}

Other assumptions: $\beta=0.05, t_{o}=0.5, t_{g}=0.2$, and $k=0.7 R$.

*The optimal holding periods are based on use of accelerated depreciation, which is always optimal [yields a higher value of $V(70,1) / P$ than does straight line depreciation]. 
More rapid rates of deterioration in the real value of the improvements

decrease tax shelter values and, to a certain extent, the frequency of trading (compare the SL and RSY lines with $\partial R / \partial \pi=1.03$ ). Faster rates of economic depreciation cause the ratio of depreciable improvements to the total purchase price to fall more rapidly which, in turn, reduces the incremental depreciation that would be gained by a trade.

At single digit inflation rates the use of the high discount rate specification reduces the number of trades and decreases the tax shelter value. The present value of the depreciation deductions falls relative to the present value of the capital gains tax when the discount rate rises one-forone with the expected inflation rate. At 12 percent inflation, where the property is never traded, increasing the discount rate relative to expected inflation increases the value of the tax shelter by reducing the present value of the capital gains tax paid on the inflated nominal gain. Finally, note that a single trade is optimal in only a single case $(\pi=9 \%$, and low discount rate).

\section{Commercial Property}

If accelerated depreciation is used for commercial property, all depreciation (up to thelmarket value of the improvements) is recaptured as ordinary income at the time of sale. Thus, investors who choose accelerated depreciation, while able to defer ordinary income are unable to convert such income into capital gain income via depreciation. As can be seen by comparing the ACC columns in Tables 1 and 2, this severe recapture substantially reduces the value of the tax shelter for commercial relative to residential properties at low inflation rates. For $\pi=0.03, \partial R / \partial \pi=1.03$ and RSY economic depreciation, the reduction is nearly 40 percent $[(.44-.27) / .44]$. In fact, the value of 
TABLE 2

COMMERCIAL PROPERTY

OPTIMAL HOLDING PERIODS AND THE INITIAL VALUE OF THE TAX SHELTER PER DOLLAR OF ORIGINAL PURCHASE PRICE $[V(70,1) / P]$

\begin{tabular}{|c|c|c|c|c|c|c|c|c|c|}
\hline & \multirow{2}{*}{$\frac{\partial R}{\partial \pi}$} & \multirow{2}{*}{$\begin{array}{c}\text { ECONOMIC } \\
\text { DEPRECIATION }\end{array}$} & \multicolumn{2}{|c|}{$V(70,1) / P$} & \multicolumn{3}{|c|}{ HOLDING PERIOD B } & \multicolumn{2}{|c|}{ INVESTOR * } \\
\hline & & & SL & $\mathrm{ACC}$ & 1 & 2 & 3 & 4 & 5 \\
\hline \multirow{3}{*}{$\pi=3 \%$} & 1.03 & SL & .36 & .27 & 15 & 15 & 15 & 25 & \multirow{3}{*}{10} \\
\hline & 1.03 & RSY & .40 & .27 & 15 & 15 & 15 & 15 & \\
\hline & $1.03 / 0.7$ & RSY & .30 & .27 & 15 & 15 & 15 & 25 & \\
\hline \multirow{3}{*}{$\pi=6 \%$} & 1.03 & SL & .23 & .22 & 15 & 15 & 15 & 25 & \\
\hline & 1.03 & RSY & .27 & .23 & 15 & 15 & 15 & 25 & \\
\hline & $1.03 / 0.7$ & RSY & .21 & .23 & 70 & & & & \\
\hline \multirow{3}{*}{$\pi=98$} & 1.03 & SL & .16 & .18 & 70 & & & & \\
\hline & 1.03 & RSY & .16 & .20 & 70 & & & & \\
\hline & $1.03 / 0.7$ & RSY & .17 & .20 & 70 & & & & \\
\hline \multirow{3}{*}{$\pi=12 \%$} & 1.03 & SL & .09 & .11 & 70 & & & & \\
\hline & 1.03 & RSY & .09 & .11 & 70 & & & & \\
\hline & $1.03 / 0.7$ & RSY & .15 & .17 & 70 & & & & \\
\hline
\end{tabular}

Other assumptions : $\beta=0.05, t_{0}=0.5, t_{g}=0.2$, and $k=0.7 R$.

* The holding optimal periods are based on use of the optimal depreciation method. 
accelerated depreciation is so reduced at low inflation rates that straightline depreciation is preferred. The selection of the straight-line method reduces the above-noted 40 percent disadvantage of commercial property relative to residential property to about 10 percent $[(.44-.40) / .44]$. At 6 percent inflation (and $\partial \mathrm{R} / \partial \pi=1.03$ with $\mathrm{RSY}$ ), the relative disadvantage is reduced from 30 percent to 18 percent.

At high inflation rates, the property is never traded. When the land is sold, the market value of the improvements is zero. Thus the recapture provision does not penalize the use of accelerated depreciation. As a result, its greater deferral benefits cause it to be preferred to straight-line depreciation.

The Cost of Suboptimal Trading

Marginal investors will earn the required rate of return on equity only if they follow the optimal trading strategy. In this section, the cost of suboptimal trading is deduced. The cost has been computed in two ways. First, we calculate the percentage decrease in the initial wealth of the initial investor owing to his use of various suboptimal strategies.' This percentage decrease equals the reduction in the value of the tax shelter caused by suboptimal trading of this investor only divided by the investor's initial equity investment which is assumed to be 20 percent of the purchase price. Second, we compute the difference between the required and actual rates of return on equity for each suboptimal trading strategy. 13 Results are reported for residential and commercial property in a world with 6 percent expected inflation.

Consider the costs of suboptimal trading for residential property displayed in Table 3. The penalty for early trading decreases through the 


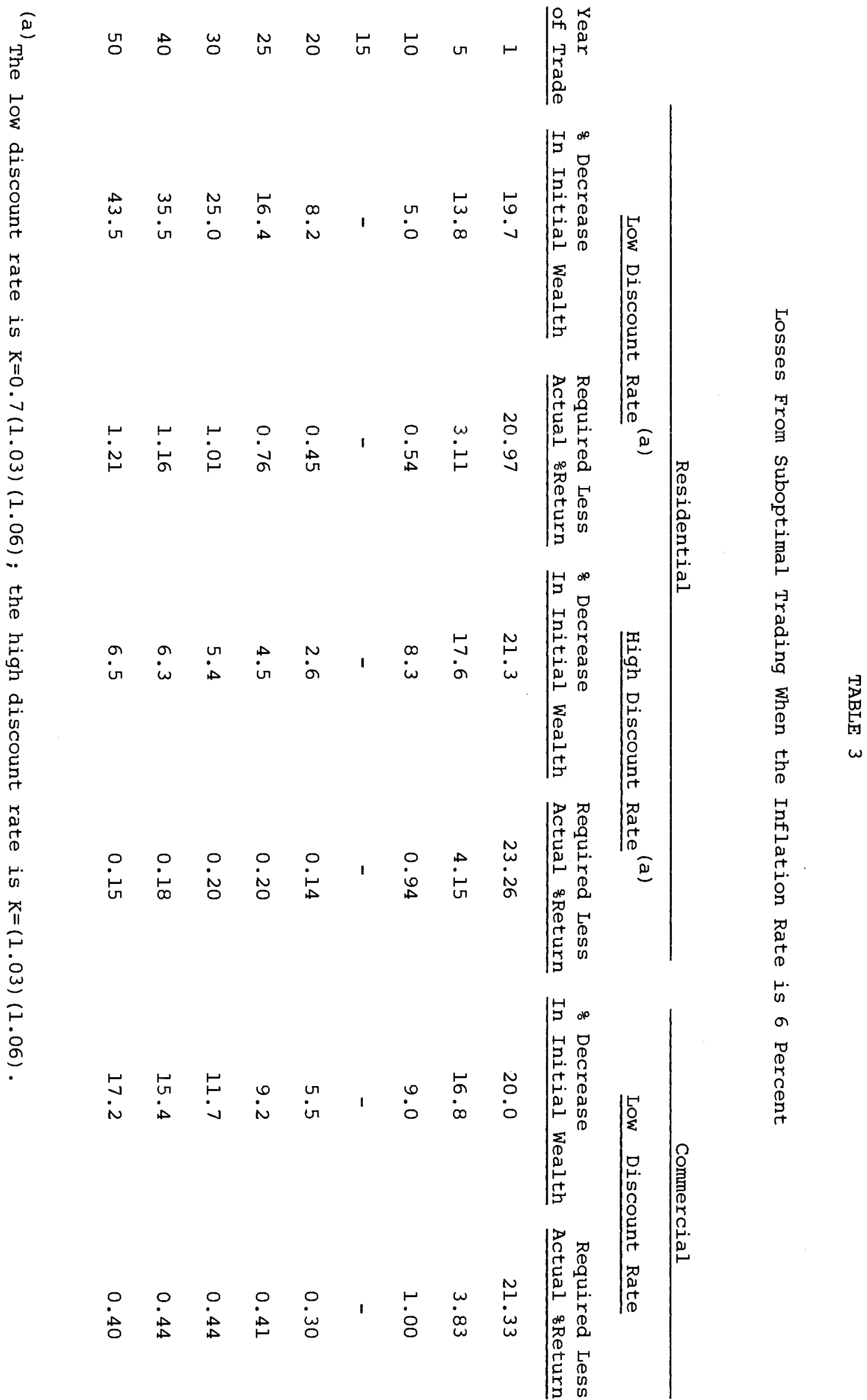


cost recovery period; conversely, the penalty for late trading increases the longer the property is suboptimally held. The losses are substantial either for trading too early or too late, except when the discount rate is high and the trade is late. Trading 10 years too early under either discount rate specification or 10 years too late in the low discount rate case gives losses of initial wealth on the order of 15 percent. In contrast, with a high discount rate, waiting too long costs little in present value terms. The 15 percent losses for trading too early translate into very large differences between required and actual annual rates of return ( 3 or 4 percent) because the losses are spread out over so few years. While the loss is significantly smaller on an annual basis, even for the low discount rate case, for trading in the 30th year instead of the 15th -- one percent, the below-market return is earned for a full thirty years.

The results for suboptimal trading of commercial properties are shown in the right side panels of Table 3. The losses for trading early are greater for commercial than residential property (at the same low discount rate) but the losses for trading late are less. Both follow from the fact that straight-line tax depreciation is optimal for commercial property while accelerated tax depreciation is for residential property. By not trading at the end of the cost recovery period, investors postpone the realization of accrued capital gains but they also delay the establishment of a new depreciable basis. This delay is more costly, in present value terms, when accelerated depreciation is employed, i.e., for residential property. Conversely, by trading prior to year 15, investors realize capital gains prematurely. The cost of this strategy, however, is partially offset by the establishment of a new depreciable basis, the value of which is greater if accelerated depreciation is used. 


\section{A Degression: The Impact of Inflation}

Comparisons of tax shelter values in Tables 1 and 2 across inflation rates, holding the discount rate and pattern of economic depreciation constant, suggest that inflation reduces returns to income property. More specifically, net tax shelter values for residential properties with RSY depreciation, reproduced in Columns (1) and (3) of Table 4, decline monotonically with increases in the inflation rate. In the low discount rate case, an increase in expected inflation from 3 to 12 percent cuts the tax shelter value by three-quarters; in the high discount rate case, the tax shelter value is halved. But this does not necessarily mean a lower total return. While increases in expected inflation decrease tax shelter values owing to the use of historic cost depreciation and the taxation of nominal capital gains, these increases tend to raise the terminal value of the property (the land value in the 70th year), although not necessarily in present value terms. ${ }^{14}$

The combined present value (per dollar of initial price) of the tax shelter and terminal land sale for residential properties is listed in columns 2 and 4 of Table 4 for different levels of expected inflation under the low and high discount rate scenarios. Because land is assumed to be 20 percent of the initial purchase price and land is assumed to rise in value at the general inflation rate, these data are computed as

$$
\frac{V(70,1)}{P}+\frac{(1+\pi)^{70} 0.2}{(1+K)^{70}}
$$


TABLE 4

The Impact of Inflation

Low Discount Rate

High Discount Rate

$3 \%$

68

98

$12 \%$
Tax Shelter Value Tax shelter Plus Iand

.44

.33

.20

.11
.53

.48

.46

.55
Tax Shelter Value Tax Shelter Plus Land

.34 .36

.24

.26

.20

.22

.17

.20 
At low discount rates $[\partial \mathrm{K} / \partial \pi=0.7(1.03)]$, greater inflation increases the terminal land value; when inflation enters the double digit range, this increase is sufficient to raise the combined value of the tax shelter and land (compare columns 1 and 2$)$. In the high discount rate case $(\partial \mathrm{K} / \partial \pi=1.03)$, the inclusion of land has a negligible effect on tax shelter values over the entire range of inflation rate scenarios (compare columns 3 and 4 ) because the inflation and discount factors applied to the land effectively cancel.

\section{SUMMARY AND CONCLUSIONS}

For well-diversified investors the trading decision for investment properties will be made with the sole objective of maximizing the value of the property's depreciation tax shelter (net of all selling costs). Sales will be timed to achieve the best compromise between postponing capital gain tax payments (and sales costs) and the cost of keeping the old depreciation base

in the face of rising nominal property prices. A dynamic programming model is developed to reflect the fact that all owners of the property will pursue optimal trading and depreciation strategies. When multiple trades occur, a more accurate, higher estimate is obtained of the value of incremental depreciation deductions resulting from a sale. The model is applied in the post-ERTA environment.

Several major conclusions follow. First, accelerated depreciation will always be chosen on residential properties, while its use is optimal for commercial properties only if trades never occur. This is due to the severe recapture penalities on commercial property. Second, optimal trading strategies on all properties will vary with the expected inflation rate and its impact on the discount rate. At low to moderate levels of anticipated inflation ( $3 \%$ and $6 \%$ ), tax-induced holding periods will be 15 years for the 
initial and a number of subsequent investors, i.e., the property will be traded when depreciation deductions are exhausted. At high levels of inflation (12\%), tax shelter benefits, net of all selling costs, will be maximized if the initial investor holds the property for its entire economic life. With high inflation, the value of postponing capital gain tax liabilities is obviously substantial.

The cost of suboptimal trading appears to be quite large. For example, in a 6 percent inflation environment an initial investor who trades a residential property 10 years too eariy (in the fifth year rather than the 15th) losses 13.8 percent of his initial equity investment or, equivalently, earns an annual rate of return 3 percentage points below the market return. The corresponding figures for trading 10 years too late are 16.4 percent and 1 percentage point (note that this point is lost for a full 25 years). Finally, in only one of 14 cases analyzed in which trading occurs is a single trade optimal. 


\section{Footnotes}

${ }^{l}$ Brueggeman, Fisher and Stern extend the model that was developed by Brannon and Sunley (1976) to investigate the various rationales for recapture. Alberts and Castanias (1982) consider how frequently an infinite-lived investor would trade identical properties. Their analysis does not address the issues of how often a given property is traded or what is the value of its tax shelter characteristics.

Before passage of the Economic Recovery Tax Act (ERTA), cost recovery periods ranged from 30 to 45 years, significantly longer than the 15 years allowed under ERTA. For this reason, the single-trade model understated total tax benefits less under pre-ERTA tax law than under the new law.

2 The development in this section follows Brueggeman, Fisher, and stern (1981). Implicit in their analysis, and ours also, is that investors can separate the management of the real estate tax shelter portion of their portfolio from their overall portfolio allocation problem.

${ }^{3}$ As Brueggeman, Fisher, and Stern (1981) point out, the distribution of $\Delta \mathrm{V}_{\mathrm{O}}$ between buyer and seller is not important for our purposes. Note that the model could also be applied to a single investor who anticipates the simultaneous purchase of a perfect substitute at the time of sale. In this case, $\Delta \mathrm{V}_{\mathrm{O}}$ would represent the amount that this same investor would gain or lose relative to the Treasury if he traded for a perfect substitute in year s.

4 Dynamic Programming is a simulation optimization technique well established in the decision science literature [see, for example, Bellman and Kalaba (1965) and Gluss (1972)]. This technique is employed because the interaction between the tax code and real estate investment behavior is difficult to address in a purely theoretical framework. The simplifying assumptions that must be made in order to derive analytical solutions can severely limit the 
applicability of the results. For example, when analyzing the effect of inflation on the real value of tax depreciation, it is typically assumed that the asset is never traded in order to derive an analytical expression [see, for example, the appendix in Feldstein, Green, and Sheshinski (1976)]. Such an assumption overstates the negative impact of inflation on the real value of tax depreciation over the life of the property if it would be optimal for a trade to occur.

5 For straight-line depreciation, the factor is a constant throughout the recovery period equal to $6.7 \%$. For accelerated depreciation the ACRS factors are: $12 \%$ in year $1,10 \%$ in year $2,9 \%$ in year $3,8 \%$ in year $4,7 \%$ in year 5 , $6 \%$ in years 6 through 9 , and $5 \%$ in years 10 through 15 .

${ }^{6}$ If accelerated depreciation is employed, then

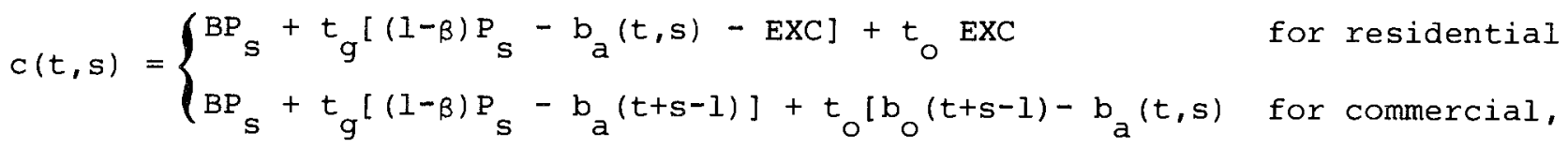

where EXC is excess depreciation. Note that in all cases the terms multiplied by $t_{g}$ correspond to $G_{S}$ in equation (4) and those multiplied by $t_{0}$ to $R_{S}$.

7 The value of the depreciation deduction to the marginal investor is assumed to be unaffected by minimum tax considerations. [On the operation of this tax, see Sirmans (1980).]

${ }^{8}$ To clarify the notation, consider the form of equation (9) in the first year of the decision making process:

$$
\mathrm{V}(70,1)=\operatorname{MAX}\left[\frac{(70,1, a)}{(1+K)}+\frac{V(69, j)}{(1+K)}\right]
$$

The net return to the first investor in stage 70 and the tax age of the improvements in the next stage (69) are a function of the trading decision 
made in stage 70. If the property is sold $(a=2$ and $j=1)$, then the tax age of the improvements in stage 69 will be 1 . If the property is not sold (a $=1$ and $j=s+1)$, then the tax age of the improvements in stage 69 will be 2 . Note the recursive nature of the problem. The optimal trading decision and the resulting tax shelter value depend on the value of the tax shelter in stage 69 which, in turn, depends on the (optimal) trading decisions of all future investors.

${ }^{9}$ Alberts and Castanias (1982) simulate the effects of inflation on investment value and optimal holding periods, but they do not allow nominal mortgage rates and after-tax discount rates to vary with the level of inflation. As a result, increases in inflation greatly increase value.

${ }^{10}$ Loan amortization and rising nominal asset prices reduce loan-to-value ratios through time, implying larger equity investments and smaller interest deductions. If an investor can costlessly maintain an optimal loan-to-value ratio, then financing will not affect trading because, at the margin, the cost of debt and equity capital are the same. If refinancing is costly more expensive than initiating a new loan on a similar property, then financing considerations may induce more frequent trading because of the gains from reestablishing the optimal loan-to-value ratio.

${ }^{11}$ Transactions costs levels of 3 and 7 percent were also considered. Results were insensitive to these variations because these costs are small relative to capital gains taxes, the other component of selling costs.

${ }^{12}$ In the simulations, all investors over the life of the property have been assumed to employ the same depreciation method (either accelerated or straight-line). The relative advantage of accelerated depreciation is understated if it is optimal for a later investor to switch to straight-line. 
13 The actual average rate of return on the $20 \%$ equity investment was obtained by solving

$$
r=(1+K)\left[1-\frac{R V}{E Q}\right]^{-t}-1,
$$

where $r$ is the average annual return, $R V$ is the reduction in the value of the tax shelter caused by suboptimal trading, $E Q$ is the equity investment, $t$ is the holding period, and $\mathrm{K}$ is the required rate of return.

${ }^{14}$ The present value of net operating rents, too, could well be affected by the level of expected inflation, but this response depends on general equilibrium considerations that are far beyond the scope of the present paper. 


\section{References}

William W. Alberts and Richard P. Castanias, II, "The Impact of Changes in Tax Depreciation Rates on Holding Periods for Real Estate Investments, " National Tax Journal, Vol. XXXV (March 1982).

R. E. Bellman and R. Kalaba, Dynamic Programming and Modern Control Theory (New York: Academic Press, 1965).

Gerald M. Brannon and Emil M. Sunley, "The Recapture of Excess Depreciation on the Sale of Real Estate," National Tax Journal, Vol. XXIX, No. 4 (December 1976).

William B. Brueggeman, Jeffrey D. Fisher and Jerold J. Stern, "Federal Income Taxes, Inflation and Holding Periods for Income Producing Property," AREUEA Journal, Vol. 9, No. 2. (Summer 1981).

William B. Brueggeman, Jeffrey D. Fisher, and Jerold J. Stern, "Rental Housing and the Economic Recovery Tax Act of 1981," Public Finance Quarterly, Vol. 10 (April 1982).

Martin Feldstein, Jerry Green and Eytan Sheshinski, "Inflation and Taxes in a Growing Economy with Debt and Equity Finance," Journal of Political Economy, Vol. 86, No. 2 (1978)

Brian Gluss, An Elementary Introduction to Dynamic Programming (Boston: Allyn and Bacon Inc., 1972).

C. R. Hulten and F. C. Wycoff, "Empirical Evidence on Economic Depreciation of Structures," 1978 Compendium of Tax Research, Washington, D.C., Treasury Department.

C. F. Sirmans, "Minimum Tax, Recapture and Choice of Depreciation Methods," AREUEA Journal, Vol. 8, No. 3 (Fall 1980).

Paul Taubman and Robert $\mathrm{H}$. Rasche, "Economic and Tax Depreciation of Office Buildings," National Tax Journal, Vol. XXII (September 1969). 